\title{
Comparative trial of perhexiline maleate and oxprenolol in patients with angina pectoris
}

\author{
J. PILCHER \\ M.D., M.R.C.P., D.C.H. \\ Walsgrave Hospital, Clifford Bridge Road, Walsgrave, Coventry CV2 2DX
}

\begin{abstract}
Summary
A random single-blind study of oxprenolol against perhexiline has been undertaken in angina pectoris. Both drugs were effective in treatment $(P<0.01)$ but perhexiline was better than oxprenolol $(P<0.05), 12$ of the 14 patients preferring perhexiline. Offset against this was the greater incidence of side effects with perhexiline, including one patient who later developed peripheral neuropathy. Despite the greater efficacy of perhexiline, it is suggested that side effects should preclude its routine prescription as a drug of first choice in angina pectoris. It should remain of value in the special situations of resistant angina and angina with heart failure or bronchospasm, when its use should be carefully monitored for these side effects.
\end{abstract}

\section{Introduction}

Perhexiline has been previously shown to be effective in the treatment of angina pectoris due to coronary artery disease (Burns-Cox et al., 1971; Hoekenga et al., 1973). The mode of action is not fully understood but haemodynamic studies in man suggest that exercise-induced ischaemia is reduced by allowing better oxygen extraction by the myocardium and by reduction of heart rate on exercise (Pepine, Schang and Bemiller, 1973; Morgans and Rees, 1973). Heart rate is not reduced at rest when taking perhexilene, as it is when taking $\beta$-blockers.

This study compared the efficacy of perhexiline against that of the $\beta$-blocking agent, oxprenolol, in patients with angina pectoris. It was undértaken in a single-blind random fashion.

\section{Methods}

Criteria for admission to the trial were as follows:

1. Informed consent to be obtained.

2. Patients of either sex to be aged less than 70 years and have typical exercise/emotion-induced angina pectoris (relieved by glyceryl trinitrate (GTN)) due to coronary artery disease, as proved by: (a) ischaemic type ST or T wave changes by ECG; or

(b) a past documented myocardial infarction; or

(c) coronary arteriographic evidence of stenosis in excess of $70 \%$.

3. Angina pectoris to have been stable in frequency over the past 3 months with attacks averaging four or more per week on no treatment other than GTN.

Patients experiencing a myocardial infarction less than three months previously were excluded, as were those with uncontrolled heart failure, diabetes, bronchospastic disease, renal or hepatic dysfunction, sinus bradycardia of $\leqslant 50$ beats/min, conduction defects other than first degree or unifascicular block and any concomitant disease whose treatment was likely to influence the conduct of the trial. Systemic hypertension was not a contra-indication to the trial (five patients being so affected BP $>160 / 90$ $\mathrm{mmHg}$ ) and other treatments, e.g. diuretics, lipidlowering agents, were not withdrawn.

On admission to the trial each patient was given a diary card on which to enter every day the number and severity of anginal attacks and the number of GTN tablets consumed (patients being told only to take GTN to relieve pain and not for prophylactic purposes). Patients were then seen every 2 weeks throughout the trial.

The first 4 weeks consisted of observation only to ascertain that the required anginal frequency was being met without treatment other than GTN. At the end of this period oxprenolol or perhexiline was introduced to the treatment in a random fashion, the patient not being told which drug he would receive. Over the next 6-8 weeks the dosage of each drug was then built up from the starting doses of perhexiline $100 \mathrm{mg}$ twice/day and oxprenolol $40 \mathrm{mg}$ thrice/day, either to the maximally effective (as shown by diary card) or maximally tolerated dose of either drug. Cut-off dose points were perhexiline $400 \mathrm{mg}$ daily and oxprenolol $1280 \mathrm{mg}$ daily in divided doses.

At the optimum, or maximal, dose of drug the trial period proper was begun and observations continued for the next 4 weeks. After this period perhexiline was substituted for oxprenolol or vice versa (oxprenolol dosage being reduced slowly to avoid withdrawal effects). After a second build-up period observations were again made over a 4-week period on the second drug. Observations made over these two 4-week periods form the basis of comparison between the two drugs.

At each visit diary cards were checked and enquiries made for volunteered side effects. Weight, 
pulse rate, and blood pressure were measured and a general physical examination made with particular reference to side effects. At the start of the trial and after each treatment period a resting ECG was undertaken and blood taken for liver function tests. At completion of the trial all patients were asked to give preference for one drug and their reasons were recorded.

Withdrawals from the trial were either because of unacceptable side effects or because of increase in severity of angina sufficient to merit investigation with a view to surgery.

Statistical analyses were carried out using paired ' $t$ ' tests.

\section{Results}

Twenty-one patients entered the trial. For one patient, control data do not exist and six patients were withdrawn at various stages of the trial. Although inclusion of the incomplete data available from these seven patients makes little difference to the means obtained and none to the statistical significance of the results, the subsequent analyses are in respect of the fourteen completed patients only.

Twelve men and two women, aged between 40 and 65 years (mean 52.9 years) took part. The mean daily dose of perhexiline was $328 \mathrm{mg}$ (range 200-400 $\mathrm{mg}$ ) and that of oxprenolol $651 \mathrm{mg}$ (range 240-1280 mg). Equal numbers of patients started treatment with each drug, and treatment order does not influence the results obtained.
Table 1 shows the effect of treatment on angina, $\frac{\Phi}{2}$ GTN consumption and on number of pain-free daysc. per week. From an average of over twenty-seven $\Rightarrow$ angina attacks per week during the control period $\stackrel{5}{?}$ there was a significant $(P<0.01)$ reduction with both? drugs. The reduction in number of attacks with perhexiline was, however, greater $(84 \%)$ than with $\frac{\bar{c}}{7}$

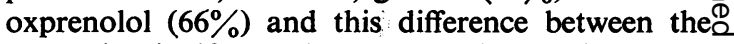
drugs is significant $(P<0.05)$. Figures for GTN@ consumption and for pain-free days per week showsimilar results with both drugs being effective but ${ }^{\circ}$ oxprenolol the less effective of the two.

Table 1 also shows effects of the drugs on hearto rate, blood pressure and on weight. Heart rate and $\bar{Q}$ both systolic and diastolic pressures were reduced $\mathrm{B}$. by oxprenolol $(P<0.02)$. No significant differences was noted on perhexiline. There was a tendency too lose weight on perhexiline and to gain weight on oxprenolol $(P<0.02)$, the maximum weight-loss being $6.6 \mathrm{~kg}$ on perhexiline and the maximum gainw $4.0 \mathrm{~kg}$ on oxprenolol. Transarninase elevation was? seen in four patients on perhexiline to a maximumSGPT of 176 (hospital normal 40). One patient on oxprenolol had an SGOT of 47. All these abnormaf transaminases settled to normal after a change of drug. There were no significant resting ECG changes. on either drug.

Six patients were withdrawn from the trial. Therre were two deaths from coronary thrombosis (one onp each drug and both during the first period of treatment). One patient, who had previously

TABLE 1.

\begin{tabular}{|c|c|c|c|c|c|}
\hline & Control & Oxprenolol & Perhexiline & Statistical significa & nce \\
\hline $\begin{array}{l}\text { Angina } \\
\text { Mean attacks/week } \\
\pm \text { s.e. mean }\end{array}$ & $\begin{array}{c}27 \cdot 25 \\
7 \cdot 1\end{array}$ & $\begin{array}{l}9 \cdot 1 \\
2 \cdot 2\end{array}$ & $\begin{array}{l}4 \cdot 1 \\
1 \cdot 2\end{array}$ & $\begin{array}{l}\text { Control v. oxprenolol } \\
\text { Control v. perhexiline } \\
\text { Perhexiline v. oxprenolol }\end{array}$ & 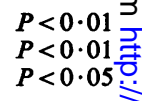 \\
\hline $\begin{array}{l}\text { Glyceryl trinitrate consumption } \\
\text { Mean tablets/week } \\
\pm \text { s.e. mean }\end{array}$ & $\begin{array}{r}21 \cdot 6 \\
7 \cdot 1\end{array}$ & $\begin{array}{l}7 \cdot 1 \\
2 \cdot 3\end{array}$ & $\begin{array}{l}3 \cdot 2 \\
0.9\end{array}$ & $\begin{array}{l}\text { Control v. oxprenolol } \\
\text { Control v. perhexiline } \\
\text { Perhexiline v. oxprenolol }\end{array}$ & $\begin{array}{r}P<0.05 \frac{0}{3} \\
P<0.05 \\
\text { n.s. }\end{array}$ \\
\hline $\begin{array}{l}\text { Angina } \\
\text { Days free/week } \\
\pm \text { s.e mean }\end{array}$ & $\begin{array}{l}0 \cdot 94 \\
0 \cdot 35\end{array}$ & $\begin{array}{l}2 \cdot 36 \\
0 \cdot 55\end{array}$ & $\begin{array}{l}4 \cdot 2 \\
0 \cdot 69\end{array}$ & $\begin{array}{l}\text { Control v. oxprenolol } \\
\text { Control v. perhexiline } \\
\text { Perhexiline v. oxprenolol }\end{array}$ & $\begin{array}{l}P<0.05 \AA \\
P<0.00 \mathrm{~B} \\
P<0.05 \mathrm{O}\end{array}$ \\
\hline $\begin{array}{l}\text { Heart rate } \\
\text { Beats/minute } \\
\pm \text { s.e. mean }\end{array}$ & $\begin{array}{r}81 \cdot 3 \\
3 \cdot 1\end{array}$ & $\begin{array}{r}67 \cdot 6 \\
1 \cdot 2\end{array}$ & $\begin{array}{r}79 \cdot 5 \\
2 \cdot 4\end{array}$ & $\begin{array}{l}\text { Control v. oxprenolol } \\
\text { Control v. perhexiline } \\
\text { Perhexiline v. oxprenolol }\end{array}$ & $\begin{aligned} P & <0.01 \\
\text { n.s. } & \text { 住 } \\
P<0.01 & \text { N }\end{aligned}$ \\
\hline $\begin{array}{l}\text { Systolic BP } \\
\mathrm{mm} \mathrm{Hg} \\
\pm \text { s.e. mean }\end{array}$ & $\begin{array}{l}156 \\
5 \cdot 7\end{array}$ & $\begin{array}{l}138 \\
5 \cdot 3\end{array}$ & $\begin{array}{l}145 \\
5 \cdot 3\end{array}$ & $\begin{array}{l}\text { Control v. oxprenolol } \\
\text { Control v. perhexiline } \\
\text { Perhexiline v. oxprenolol }\end{array}$ & $\begin{array}{r}P<0.02^{-} \cdot n \\
\text { n.s. } \\
\text { n.s. N }\end{array}$ \\
\hline $\begin{array}{l}\text { Diastolic BP } \\
\mathrm{mm} \mathbf{H g} \\
\pm \text { s.e. mean }\end{array}$ & $\begin{array}{l}90 \\
2 \cdot 4\end{array}$ & $\begin{array}{l}84 \\
1.4\end{array}$ & $\begin{array}{l}88 \\
1 \cdot 7\end{array}$ & $\begin{array}{l}\text { Control v. oxprenolol } \\
\text { Control v. perhexiline } \\
\text { Perhexiline v. oxprenolol }\end{array}$ & 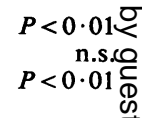 \\
\hline $\begin{array}{l}\text { Weight } \\
\text { Mean change in } \mathbf{~ g ~} \\
\pm \text { s.e. mean }\end{array}$ & - & $\begin{array}{r}+1.92 \\
0.64\end{array}$ & $\begin{array}{r}-1.04 \\
0.79\end{array}$ & Perhexiline v. oxprenolol & $P<0.02 \frac{T}{0}$ \\
\hline
\end{tabular}


TABLE 2. Side effects (from fifteen patients)

\begin{tabular}{|c|c|c|c|}
\hline \multicolumn{2}{|l|}{ Perhexiline } & \multicolumn{2}{|l|}{ Oxprenolol } \\
\hline Side effect & $\begin{array}{l}\text { No. of } \\
\text { patients }\end{array}$ & Side effect & $\begin{array}{l}\text { No. of } \\
\text { patients }\end{array}$ \\
\hline Nausea & 2 & Nausea & 1 \\
\hline Giddiness & 3 & Abdominal symptoms & 3 \\
\hline Headache & 1 & Headache & 1 \\
\hline Abdominal symptoms & 3 & Palpitations & 1 \\
\hline Insomnia & 1 & Rash & 1 \\
\hline Impotence & 1 & Bronchospasm & 1 \\
\hline Tingling legs & 1 & Impotence & 1 \\
\hline Muscle pain & 1 & & \\
\hline Poor concentration & 1 & & \\
\hline Pressure at temples & 1 & & \\
\hline Total patients & 9 & Total patients & 7 \\
\hline Total side effects & 15 & Total side effects & 9 \\
\hline
\end{tabular}

responded well to perhexiline, was withdrawn on oxprenolol because of severe indigestion. The remaining three patients were withdrawn during treatment with oxprenolol (one after receiving perhexiline and two before) because of angina at rest, which required subsequent surgical intervention.

Subjective side effects not necessitating withdrawal from the trial are given in Table 2 for the fifteen patients who completed both drug regimes; six patients had no side effects to either drug, while seven patients had side effects to both. Although most side effects were of short duration, in five patients they were sufficient to cause dose limitation (perhexiline $\times 5$; oxprenolol $\times 2$ ). One patient developed peripheral neuropathy on perhexiline some 6 months after completion of the trial.

All patients thought both drugs had helped their angina. When asked to express preference, twelve chose perhexiline and two oxprenolol.

\section{Discussion}

After any new drug has been established as being markedly better than placebo in the treatment of a disease it is logical to test that drug against known effective therapy. This has been done for oxprenolol against other $\beta$-blocking agents (e.g. Sharma et al., 1971). It is as effective in angina pectoris as other drugs of its class. Perhexiline has been previously tested against both placebo and the $\beta$-blocking drugs propranolol and practolol (Armstrong et al., 1974).

Whilst both drugs were markedly better than placebo, as in this study, perhexiline was also significantly more effective than the $\beta$-blockers. However, a possible criticism of that trial relates to the doses of propranolol and practolol used.

It is now a notorious fact that the common reason for 'failure' of treatment by $\beta$-blocking drugs in angina pectoris relates to inadequate dosage. No such criticism can be levelled at this trial where ten of the fourteen patients were taking doses of oxprenolol at, or above, the manufacturer's 'usual maximum dose' of $480 \mathrm{mg}$ daily. However, a criticism of this study will be the failure to use a double blind method of investigation thereby allowing possible investigator bias.

Unlike oxprenolol, perhexiline has a narrow doseeffective range which poses technical problems in double blinding. More importantly, oxprenolol reduces pulse rate at rest, whilst perhexiline does not. The reduction of pulse rate is obvious and is used as an indication of dose-effectiveness of oxprenolol. Accordingly, it was felt that a double blind trial would not be truly blind and that sub-therapeutic doses of oxprenolol might well be used. Hence the random single blind technique adopted.

Comparing two drugs with each other raises further problems. Firstly, that the order of treatment may influence the results, possibly owing to inadequate washout of either drug or to a placebo effect. The washout period between optimum doses of either drug was in no case less than 6 weeks and analysis of the results shows no effect due to the order of treatment. Secondly, any trial using two active drugs is likely to increase the number of side effects observed and such seems to be the case in this study. More subjective side effects were seen with perhexiline than with oxprenolol. In all except one patient on oxprenolol these side effects were doserelated and could be made tolerable by reducing the dose. Dose limitation involved perhexiline more than oxprenolol $(5: 2)$ and it was despite this that the results indicated perhexiline to be the more effective of the two drugs in treatment. Patient preference was affected by side effects in one patient who preferred oxprenolol even though this drug was less effective in anginal relief. The other four patients concerned felt anginal relief to be more important than side effects.

Objective side effects in a trial such as this are 
short term. One patient on oxprenolol developed asymptomatic bronchospasm but none heart failure on either drug. Perhexiline is recognized as causing transaminase elevation (Burns-Cox et al., 1971) and did so in this trial in four patients. It is not clear what the cause of this transaminase elevation may be. It is known to regress when treatment is withdrawn and may regress on dose reduction as happened in one patient in this trial whose dose was reduced because of digestive symptoms with attendant reduction in SGPT from 176 to 100 units. However, transaminase elevations are unpredictable and SGOT and SGPT should be measured at intervals, the dose being reduced or withdrawn if the enzyme level approaches three to four times the normal value.

Hypoglycaemia as a result of perhexiline has been reported (Roger et al., 1975) but there were no symptoms suggestive of this in this study. Severe weight-loss seems a more definite side effect (Grand and Sepulcre, 1974) and it is interesting that there was a significant difference in weight-change between perhexiline and oxprenolol in this study, the maximum loss being $6.6 \mathrm{~kg}$ with perhexiline over 11 weeks.

The major side effects of perhexiline are neurological and of these psripheral neuropathy is the most important. Originally reported by Abaza et al. in 1973, peripheral neuropathy due to the drug has now been confirmed by many other authors. Whether this is due primarily to a demyelinating disorder as suggested by Bousser et al. (1977) or due to axonal toxicity as yet remains uncertain. It appears to be mainly confined to 'slow' metabolizers of the drug (Singlas, 1977) who form a minority $(15-20 \%)$ of the population, at least as studied in the U.S.A. (Wright, 1976). Peripheral neuropathy usually occurs after long-term administration as it did in one patient from this study some months after completion of the trial and in two other patients not part of the trial - all confirmed by electromyography. Repeat electromyograms some 6 to 12 months after cessation of the drug were normal in two cases and much improved in the third, these findings being in keeping with the clinical assessment. Such improvement in peripheral neuropathy after cessation of the drug is similar to that found in all studied cases to date.

The main other neurological complication after long-term administration of perhexiline is papilloedema, often in association with peripheral neuropathy (Bousser et al., 1976; Bousser et al., 1977), and occasionally with loss of visual acuity and ataxia (Stephens et al., 1978). Whether this papilloedema represents a true rise in intracranial pressure is still being discussed but, like peripheral neuropathy, it too resolves on cessation of the drug. Other reports of neurological complications to the drug include dysarthria and deafness (Epstein 1977), extrapyramidal syndromes, cerebellar ataxia and mental slowing (Arnott et al., 1977); but thesecomplications are as yet largely unconfirmed and probably rare. Peripheral neuropathy, on the other? hand, occurs with sufficient frequency to have beer? the cause of a recent warning from the Committee on Safety of Medicines, putting a considerable limif on the use of the drug in clinical practice.

It is unfortunate that perhexiline should have्en side effects that make it in many ways unsuitable foradministration in general practice. It is a mose effective treatment of angina pectoris. This study and that of Armstrong et al. (1974) suggest it to be moree effective than $\beta$-blockers. Other advantages are itso lack of effect on bronchial muscle or respiratory function (Sharma et al., 1973), and its mild diureticin effect (Czerwinski et al., 1973), its anti-arrhythmicos properties (Drake et al., 1973), and its lack of any myocardial depressant action (Pepine et al., 1973) However, despite all these advantages, it does nok seem a drug best suited for first choice treatment of angina pectoris.

Nevertheless, whilst failure of response to con-응 ventional $\beta$-blocking therapy in angina pectorisơ should lead to consideration of surgery, many patients exist whose disease is not amenable to surgery. Perhexiline should be considered in these patients. It is a personal impression that resistamp angina responds better to the use of perhexiline an $\beta$-blocking drug concurrently than to either drug individually. This could be expected in view of theiro differing modes of action but no definite data exist.๊ Finally, perhexiline seems a logical drug for use in $\frac{\mathbb{Q}}{\square}$ patients with bronchospasm or heart failure. For these special categories of patients the potential benefit obtainable would seem to outweigh the added 5 risk of its side effects.

\section{Acknowledgments}

I am grateful to Dr A. Barr of the Oxford Regional Health Authority for conducting the statistical analyses and to Dr J. D. F. Lockhart of Richardson-Merrell Limited for helpo on the conduct of the trial.

\section{References}

Abaza, A., Cattan, D., Aziza, C. \& Pappo, E. (1973) Effets secondaires mais reversibles à la prise de perhexiline. N Nouvelle Presse Médicale, 2, 2820.

Armstrong, M.L., Brand, D., Emmett, A.J., Hodge, N J.L.R., Kellaway, G.S.M., Mestitz, P., Reefman, M. \&N WALlaCe, D.C. (1974) A multicentre trial of perhexiline ${ }^{\omega}$ maleate, beta blocker and placebo in angina pectoris $\sigma$ Medical Journal of Australia, 2, 389.

Arnott, G., Masingue, M., Berenstein-Fortier, S., Hache, J.C., Boulenge-Beaussart, L. \& MichauX, F.' (1977) Polyradiculonévrite, manifestations cérébelleuses, tremblement parkinsonien, oedème papillaire et hémor- $\square$ ragies au fond d'oeil au cours d'un traitement par le음 maléate de perhexiline. Lille médical, 22, 168. 
Bousser, M.G., Bouche, P., Brochard, C. \& Herreman, G (1976) Neuropathies péripheriques au maléate de perhexiline; à propos de 7 observations. Coeur et Médecine Interne, 15, 181.

Bousser, M.G., Bouche, P., Hauw, J.J., Singlas, E., Touboul, P.J. \& LaPIANe, D. (1977) Neuropathies péripheriques au maléate de perhexiline. Annales de cardiologie, 26 (Suppl.), 493.

Burns-Cox, C.J., Chandrasekhar, K.P., IKram, H., Peirce, T.H., Pilcher, J., Quinlan, C.D.M. \& Rees, J.R. (1971) Clinical evaluation of perhexiline maleate in patients with angina pectoris. British Medical Journal, 4, 586.

Czerwinski, A.W., Czerwinski, A.B., Whitsett, T.L. \& Clark, M.L. (1973) A controlled study of the diuretic and natriuretic properties of perhexiline maleate in normal human volunteers. Fostgraduate Medical Journal, 49 (Suppl. 3), 26.

Drake, F.T., Singer, D.H., Haring, O. \& Dirnberger, G. (1973) Evaluation of anti-arrhythmic efficacy of perhexiline maleate in ambulatory patients by Holter monitoring. Postgraduate Medical Journal, 49 (Suppl. 3), 52.

EPSTEIN, H. (1977) Polyneuropathy during perhexiline maleate therapy. South African Medical Journal, 51, 189.

Grand, A. \& SePUlCRe, Ph. (1974) Amaigrissement et maléate de perhexiline. Nouvelle Presse Médicale, 3, 1505.

Hoekenga, M.T., Bunde, C.A., Cawein, M.D., Kuzma, R.J. \& GriffIN, C.L. (1973) Clinical results with a new anti-anginal drug (perhexiline maleate). Postgraduate Medical Journal, 49 (Suppl. 3), 95.

Morgans, C.M. \& Rees, J.R. (1973) The action of perhexiline maleate in patients with angina. American Heart Journal, 83(3), 329.

Pepine, C.J., Schang, S.J. \& Bemiller, C.R. (1973) Alteration of left ventricular responses to ischemia with oral perhexiline. Postgraduate Medical Journal, 49 (Suppl. 3), 43.

Roger, P., Nogue, F., Ragnaud, J.M., Manciet, G. \& DoumaX, Y. (1975) Hypoglycémie après maléate de perhexiline, Nouvelle Presse Médicale, 4, 2663.

Sharma, G.V.R.K., Burleson, V.A., Mondello, N.T., BelKo, J.S. \& SASAHARA, A.A. (1973) Broncho-pulmonary effects of perhexiline maleate. Clinical Research, 21, 988.

Sharma, B., Meeran, M.K., Galvin, M.C., Tulpule, A.T., Whitaker, W., \& TAYLOR, S.H. (1971) Comparison of adrenergic beta blocking drugs in angina. British Medical Journal, 3, 152.

Singlas, E. (1977) Personal communication to Bousser, M.G. et al. (1977) (see above).

Stephens, W.P., Eddy, J.D., Parsons, L.M. \& Singh, S.P. (1978) Raised intracranial pressure due to perhexiline maleate, British Medical Journal, 1, 21.

Wright, G.J. (1976) Personal communication to Bousser, M.G. et al. (1977) (see above). 